\title{
Structural Study, Vibrational, Optical, Thermal Properties and Hirshfeld Surface Analysis of a New Iron (III) Complex: $\mathrm{FeCl}_{4}\left(\mathrm{C}_{5} \mathrm{~N}_{2} \mathrm{H}_{6}\right)\left(\mathrm{C}_{5} \mathrm{~N}_{2} \mathrm{H}_{5}\right)$
}

\author{
Amal Arouri ${ }^{1}$, Rihab Dridi $^{1}$, Riadh Kefi $^{2}$, Mohamed Faouzi Zid ${ }^{*}$ \\ ${ }^{1}$ Laboratory of Materials, Crystal Chemistry and Applied Thermodynamics, Faculty of Sciences of Tunis, University of Tunis El \\ Manar, Tunis, Tunisia \\ ${ }^{2}$ Laboratory of Chemistry of Materials, Faculty of Sciences of Bizerte, University of Carthage, Bizerte, Tunisia \\ Email: ^faouzi.zid@fst.rnu.tn
}

How to cite this paper: Arouri, A., Dridi, R., Kefi, R. and Zid, M.F. (2021) Structural Study, Vibrational, Optical, Thermal Properties and Hirshfeld Surface Analysis of a New Iron (III) Complex: $\mathrm{FeCl}_{4}\left(\mathrm{C}_{5} \mathrm{~N}_{2} \mathrm{H}_{6}\right)\left(\mathrm{C}_{5} \mathrm{~N}_{2} \mathrm{H}_{5}\right)$. Crystal Structure Theory and Applications, $10,14-26$.

https://doi.org/10.4236/csta.2021.101002

Received: January 21, 2021

Accepted: February 21, 2021

Published: February 24, 2021

Copyright $\odot 2021$ by author(s) and Scientific Research Publishing Inc. This work is licensed under the Creative Commons Attribution International License (CC BY 4.0).

http://creativecommons.org/licenses/by/4.0/

\begin{abstract}
The title compound, $\mathrm{FeCl}_{4}\left(\mathrm{C}_{5} \mathrm{~N}_{2} \mathrm{H}_{6}\right)\left(\mathrm{C}_{5} \mathrm{~N}_{2} \mathrm{H}_{5}\right)$ consists of two $\left[\left(\mathrm{C}_{5} \mathrm{~N}_{2} \mathrm{H}_{6}\right)\right.$ $\left.\left(\mathrm{C}_{5} \mathrm{~N}_{2} \mathrm{H}_{5}\right)\right]^{+}$organic cations and $\left[\mathrm{FeCl}_{4}\right]^{-}$anion. The geometry of the iron ion is tetrahedral, formed by four chlorine atoms. The complex was characterized by single crystal X-ray diffraction, Fourier Transform Infrared spectroscopy, thermal analysis and UV-Visible spectroscopy. Hirshfeld surface analysis was also used for understanding the intermolecular interactions in the crystal packing. Single-crystal X-ray diffraction analysis indicates that this complex crystallizes in the monoclinic system, $\mathrm{P} 2_{1} / \mathrm{c}$ space group with $\mathrm{a}=7.598$ (3) $\AA$, b $=13.694$ (4) $\AA, \mathrm{c}=17.105$ (5) $\AA, \beta=97.203(6)^{\circ} \mathrm{V}=1765.7$ (10) $\AA^{3}$ and $\mathrm{Z}=4$. The $\left[\mathrm{FeCl}_{4}\right]^{-}$anion and $\left[\left(\mathrm{C}_{5} \mathrm{~N}_{2} \mathrm{H}_{6}\right)\left(\mathrm{C}_{5} \mathrm{~N}_{2} \mathrm{H}_{5}\right)\right]^{+}$cations are linked through three-dimensional hydrogen-bonding network consisting of $\mathrm{N}-\mathrm{H} \cdots \mathrm{Cl}$ and $\pi-\pi$ interactions. Hirshfeld surface analysis and the related 2D fingerprint plots reveal that the complex is dominated by $\mathrm{N}-\mathrm{H} \cdots \mathrm{Cl}$ contacts.
\end{abstract}

\section{Keywords}

Complex, Crystal Structure, X-Ray Analysis, Optical Study, Thermal Analysis, Hirshfeld Surface

\section{Introduction}

The research into coordination chemistry of iron complexes with Schiff-base ligands has given rise to materials exhibiting coexistence of novel properties due to the interaction between the subnetworks.

The iron-based compounds are very interested due to their broad applications in catalysis, biology, medicine and even in agriculture [1]-[6]. On the other 
hand, pyridine derivatives are attracting increasing interest in agrochemical and pharmaceutical [7] [8]. Indeed, hydrogen-bonding is necessary for the design and development of multifunctional hybrid compounds [9] [10]. In order to extend our studies in this field, we have focused on the combination of 3-amino-2-chloropyridinium ligand with iron metal ion to constitute suitable building blocks in generating a variety of supramolecular assemblies through the hydrogen bond interactions. Furthermore, the application of Hirshfeld surface analysis is increasing in the crystallography, providing a visual picture of intermolecular interactions and of molecular shapes in a crystalline environment. We report in this present study the synthesis, structural characterization by single crystal X-ray diffraction and X-ray powder diffraction, vibrational study by infrared spectroscopy, optical properties and thermal analyses of a new iron (III) complex. The intermolecular contacts in the crystal were investigated by Hirshfeld surface analysis.

\section{Materials and Measurements}

\subsection{Experimental}

All reagents and solvents were purchased from Sigma Aldrich and used without further purification. Infrared spectrum on $\mathrm{KBr}$ pellets of the hybrid compound was obtained using Perkin Elmer Spectrum spectrophotometer in the range of $4000-400 \mathrm{~cm}^{-1}$. The UV-visible spectrum was recorded on a $2802 \mathrm{UV} / \mathrm{VIS}$ spectrophotometer (UNICO) within the range $200-800 \mathrm{~nm}$. X-ray powder diffraction measurements were collected on a BRUKER D8 ADVANCE X-ray diffractometer using $\mathrm{K} \alpha \mathrm{l}(\mathrm{Cu})(\lambda=15.406 \AA)$ radiation. Differential thermal analysis (DTA) was carried using SETARAM-TG-DTA 92-16 microthermobalance and Thermogravimetric (TG) measurement was carried out on a SETARAM SETSYS Evolution-1750 microthermobalance with an alumina tube furnace and a graphite heater.

\subsection{Synthesis of (3-Amino-2-Chloropyridinium) Tetrachloridoiron (III) $\mathrm{FeCl}_{4}\left(\mathrm{C}_{5} \mathrm{~N}_{2} \mathrm{H}_{6}\right)\left(\mathrm{C}_{5} \mathrm{~N}_{2} \mathrm{H}_{5}\right)$}

3-Amino-2-chloropyridinium ( $0.5 \mathrm{mmol} \cdot 128.56 \mathrm{mg})$ was dissolved in $5 \mathrm{~mL}$ of methanol (solution A). Anhydrous iron chloride (III) (0.33 mmol.162.2 mg) was dissolved in $5 \mathrm{~mL}$ of methanol (solution $\mathrm{B}$ ). The A solution was added dropwise in B solution, resulting in yellow solution. The reaction mixture was stirred at room temperature for 30 minutes. Then, red prismatic crystals suitable for X-ray diffraction were obtained after 3 weeks of slow evaporation at room temperature.

\subsection{Single Crystal X-Ray Structural Analysis}

A red prismatic crystal of size $(0.42 \times 0.28 \times 0.21)$ was carefully selected for the structural analysis. The raw diffraction data were collected at $298 \mathrm{~K}$ with Enraf-Nonius CAD4 automatic four-circle equipped with graphite monochro- 
mator using Mo K $\alpha$ radiation $(\lambda=0.71073 \AA$ ) [11]. The structure was solved using the SIR 2014 program [12] refined by full-matrix least squares technique on F2 through SHELXL-2014 [13]. The non-hydrogen atoms were inserted anisotropically while the hydrogen atoms were fixed using AFIX 43 instruction, $\mathrm{C}-\mathrm{H}$ = $93 \AA$ and $\mathrm{N}-\mathrm{H}=86 \AA$. An empirical psi-scan [14] absorption correction was applied $\left(\mathrm{T}_{\min }=0.694, \mathrm{~T}_{\max }=0.999\right)$.

The crystallographic data, the experimental details of the data collection and the results of refinement of the crystal structure are presented in Table 1.

DIAMOND version 3.2 program [15] was used for molecular graphics. ${ }^{*} \mathrm{CIF}$ file containing complete information about the structure of $\mathrm{FeCl}_{4}\left(\mathrm{C}_{5} \mathrm{~N}_{2} \mathrm{H}_{6}\right)\left(\mathrm{C}_{5} \mathrm{~N}_{2} \mathrm{H}_{5}\right)$ was deposited with the Cambridge Crystallographic Data Center (CCDC 2056579). The data can be obtained free of charge from the following website: http://www.ccdc.cam.ac.uk/data_request/cif.

\section{Results and Discussion}

\subsection{Crystal Structure of the Complex}

$\mathrm{FeCl}_{4}\left(\mathrm{C}_{5} \mathrm{~N}_{2} \mathrm{H}_{6}\right)\left(\mathrm{C}_{5} \mathrm{~N}_{2} \mathrm{H}_{5}\right)$ crystallizes in the monoclinic system with space group $\mathrm{P} 2_{1} / \mathrm{c}$. The asymmetric unit of the complex is made up of two independents $\left[\left(\mathrm{C}_{5} \mathrm{~N}_{2} \mathrm{H}_{6}\right)\left(\mathrm{C}_{5} \mathrm{~N}_{2} \mathrm{H}_{5}\right)\right]^{+}$organic cations, one $\left[\mathrm{FeCl}_{4}\right]^{-}$tetrahedral as illustrated in Figure 1.

Table 1. Crystal and structure refinement data for the title compound: $\mathrm{FeCl}_{4}\left(\mathrm{C}_{5} \mathrm{~N}_{2} \mathrm{H}_{6}\right)\left(\mathrm{C}_{5} \mathrm{~N}_{2} \mathrm{H}_{5}\right)$.

\begin{tabular}{|c|c|}
\hline Chemical formula & $\mathrm{FeCl}_{4}\left(\mathrm{C}_{5} \mathrm{~N}_{2} \mathrm{H}_{6}\right)\left(\mathrm{C}_{5} \mathrm{~N}_{2} \mathrm{H}_{5}\right)$ \\
\hline Formula weight $\left(\mathrm{g} \cdot \mathrm{mol}^{-1}\right)$ & 455.78 \\
\hline Temperature (K) & 298 \\
\hline Crystal system; Space group & Monoclinic; $\mathrm{P} 2_{1} / \mathrm{c}$ \\
\hline $\mathrm{a}(\AA) ; \mathrm{b}(\AA) ; \mathrm{c}(\AA) ; \beta\left(^{\circ}\right)$ & 7.598 (3); 13.694 (4); 17.105 (5); 97.203 (6) \\
\hline Volume ( 3 ); Z & $1765.7(10) ; 4$ \\
\hline Sample size $(\mathrm{mm})$ & $0.42 \times 0.28 \times 0.21$ \\
\hline Radiation, $\lambda,(\AA)$ & $\lambda=0.71073$ \\
\hline$\mu\left(\mathrm{mm}^{-1}\right)$ & 1.76 \\
\hline F000 & 908 \\
\hline$\theta$ Range $\left(^{\circ}\right)$ & $2.4 \leq \theta \leq 27.2$ \\
\hline Scan mode & $\omega-2 \theta$ \\
\hline Absorption correction & psi-scan \\
\hline $\mathrm{T}_{\min }, \mathrm{T}_{\max }$ & $0.694,0.999$ \\
\hline Number of reflections measured; & 4747 \\
\hline Independent reflections; $\mathrm{R}_{\text {int }}$ & $3806 ; 0.038$ \\
\hline Reflections with $[\mathrm{I}>2 \sigma(\mathrm{I})]$ & 1934 \\
\hline $\mathrm{R}\left(\mathrm{F}^{2}\right) ; \omega \mathrm{R}\left(\mathrm{F}^{2}\right) ; \mathrm{S}(\mathrm{GOOF})$ & $0.051 ; 0.140 ; 0.98$ \\
\hline$\Delta \rho_{\max }, \Delta \rho_{\min }\left(\mathrm{e} \AA^{-3}\right)$ & $0.50 ;-0.34$ \\
\hline
\end{tabular}




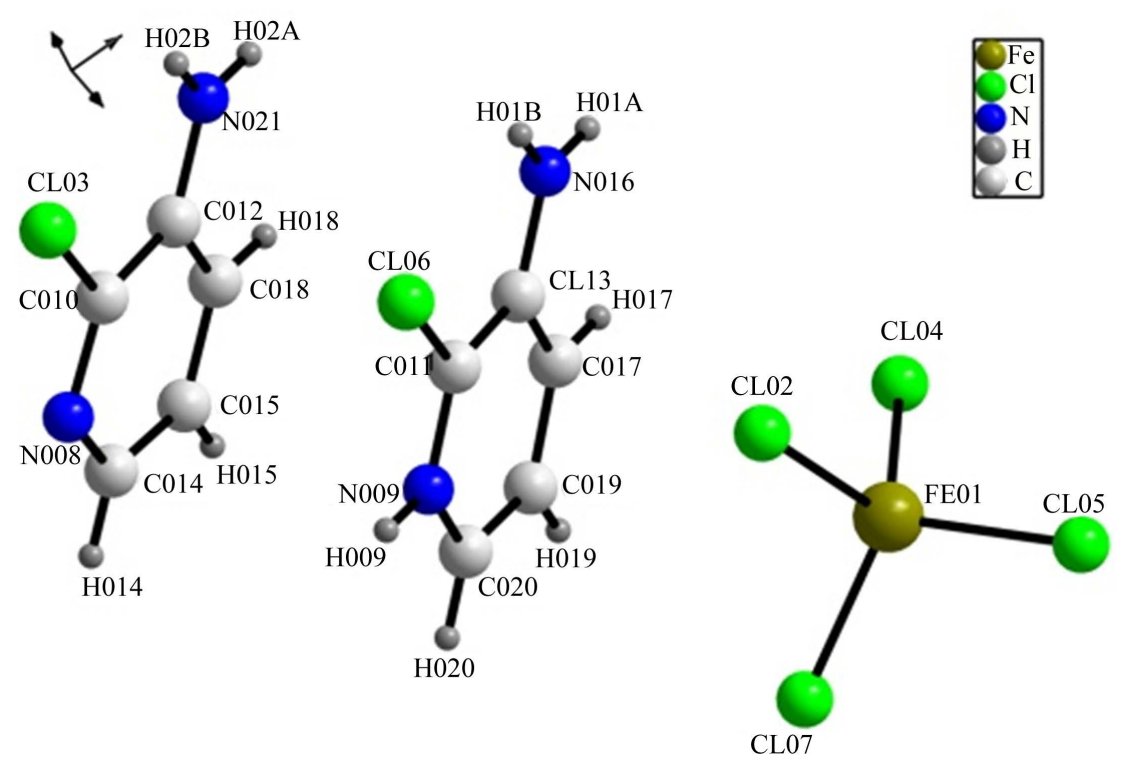

Figure 1. Asymmetric unit of $\mathrm{FeCl}_{4}\left(\mathrm{C}_{5} \mathrm{~N}_{2} \mathrm{H}_{6}\right)\left(\mathrm{C}_{5} \mathrm{~N}_{2} \mathrm{H}_{5}\right)$.

The central atom of the anionic moiety is tetracoordinated by four chlorine atoms ( $\mathrm{Cl} 02 \mathrm{Cl} 04 \mathrm{Cl} 05$ and $\mathrm{Cl} 07) . \mathrm{FeCl}_{4}$ is characterized by a range of $\mathrm{Fe}-\mathrm{Cl}$ bond length from 2.181 (7) $\AA$ to 2.187 (7) $\AA$ and the $\mathrm{Cl}-\mathrm{Fe}-\mathrm{Cl}$ angles vary from 107.882 $(3)^{\circ}$ to $111.989(3)^{\circ}$ They are comparable with the values reported for similar compounds containing the $\mathrm{FeCl}_{4}$ [16] [17]. Therefore, the calculated average values of the distortion indices as described by Baur [18] corresponding to the different angles and distances in $\mathrm{FeCl} 4$ tetrahedra, $\left(\mathrm{DI}(\mathrm{Cl}-\mathrm{Fe}-\mathrm{Cl})=0.00157^{\circ}\right.$ and $\mathrm{DI}(\mathrm{Fe}-\mathrm{Cl})=0.00301 \AA$; show a light distortion. The 3-amino-2-chloropyridinium ligand is planar and the average C-C (1.373(3) $\AA$ ), C-N (1.705 (5) $\AA$ ) and C-Cl (1.339(4) $\AA$ ) bond lengths, and the average angles (130.565 (14)) within the rings are in a good agreement with those admitted for a 3-amino-2-chloropyridinium coordinated metal complexes [19].

The crystal structure of the complex $\mathrm{FeCl}_{4}\left(\mathrm{C}_{5} \mathrm{~N}_{2} \mathrm{H}_{6}\right)\left(\mathrm{C}_{5} \mathrm{~N}_{2} \mathrm{H}_{5}\right)$ can be described as an alternation of layers between organic cations and inorganic anions into lines running along the [010] direction Figure 2.

The anions $\left[\mathrm{FeCl}_{4}\right]^{-}$are located between the cations layer along the [001] direction (Figure 3).

The $\left[\mathrm{FeCl}_{4}\right]^{-}$and $\left(\mathrm{C}_{5} \mathrm{~N}_{2} \mathrm{H}_{6}\right)^{+}$are connected via $\mathrm{N}-\mathrm{H} \cdots \mathrm{Cl}$ hydrogen bonds that link the amino $\mathrm{N}-\mathrm{H}$ group to the $\mathrm{Cl}$ atoms, forming a cations-anions interaction type by connecting the positive and the negative layers and reinforcing the cohesion of the ionic structure (Figure 4).

An additional stability of the crystal is afforded by $\pi-\pi$ interaction between the aromatic rings of the cations $\left[\left(\mathrm{C}_{5} \mathrm{~N}_{2} \mathrm{H}_{6}\right)\left(\mathrm{C}_{5} \mathrm{~N}_{2} \mathrm{H}_{5}\right)\right]^{+}$are found to be $3.739 \AA$ Figure 5.

\subsection{X-Ray Powder Diffraction}

The phase purity of our complex was checked by the Rietveld refinement. The 


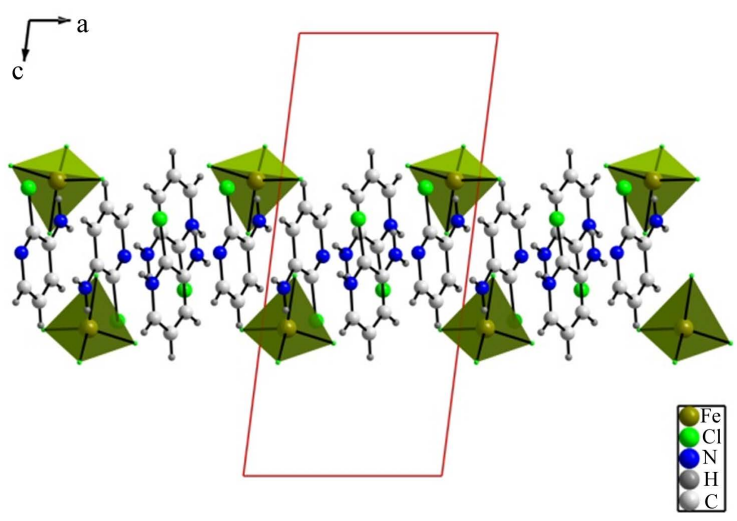

Figure 2. Projection of $\mathrm{FeCl}_{4}\left(\mathrm{C}_{5} \mathrm{~N}_{2} \mathrm{H}_{6}\right)\left(\mathrm{C}_{5} \mathrm{~N}_{2} \mathrm{H}_{5}\right)$ structure along the $\mathrm{b}$ axis.

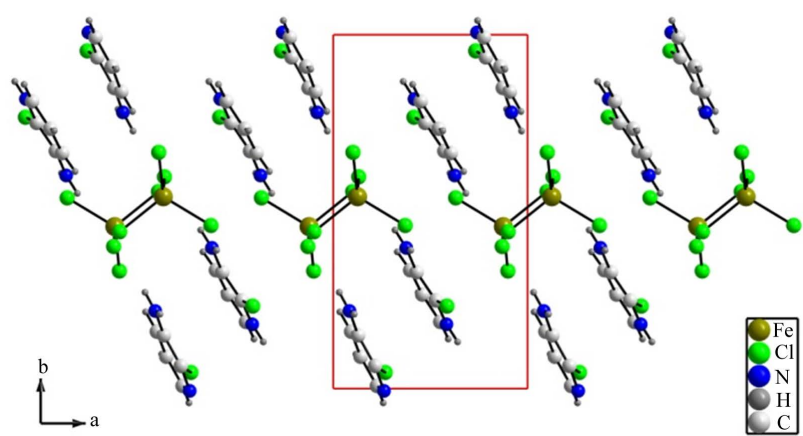

Figure 3. Projection of $\mathrm{FeCl}_{4}\left(\mathrm{C}_{5} \mathrm{~N}_{2} \mathrm{H}_{6}\right)\left(\mathrm{C}_{5} \mathrm{~N}_{2} \mathrm{H}_{5}\right)$ structure along the $\mathrm{c}$ axis.

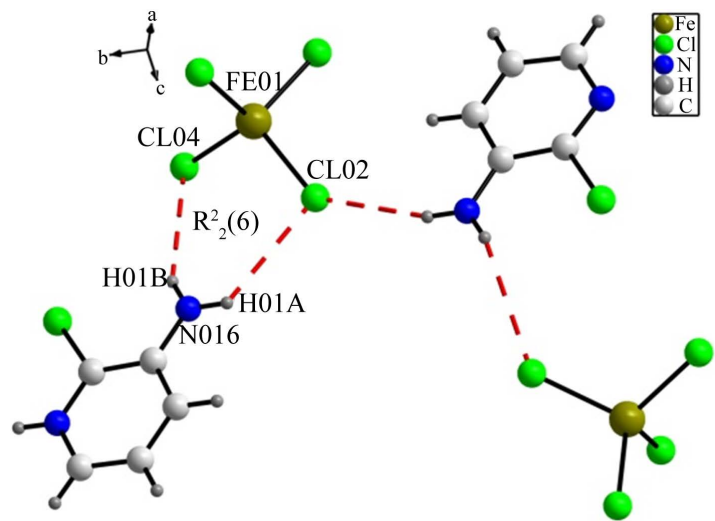

Figure 4. Fragments of $\mathrm{FeCl}_{4}\left(\mathrm{C}_{5} \mathrm{~N}_{2} \mathrm{H}_{6}\right)\left(\mathrm{C}_{5} \mathrm{~N}_{2} \mathrm{H}_{5}\right)$ the molecular structure of showing hydrogen bonding interactions.

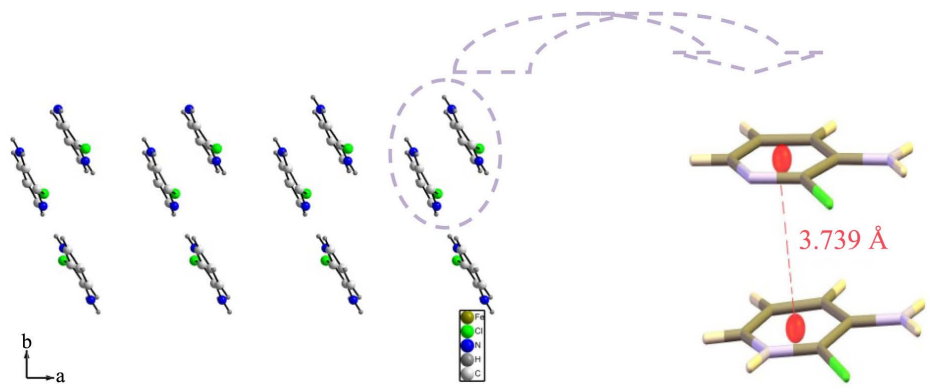

Figure 5. Representation of the cationic cycles and the interactions $\pi-\pi$. 
single crystal structure was used as a starting model. The refinement was performed using the GSAS-EXPGUI software [20] [21]. The result is fully consistent with the obtained from the single crystal diffraction data. All diffraction peaks were indexed in $\mathrm{P} 2{ }_{1} / \mathrm{c}$ space group and no additional peaks were observed. This clearly indicates the purity of our phase $\mathrm{FeCl}_{4}\left(\mathrm{C}_{5} \mathrm{~N}_{2} \mathrm{H}_{6}\right)\left(\mathrm{C}_{5} \mathrm{~N}_{2} \mathrm{H}_{5}\right)$ (Figure 6).

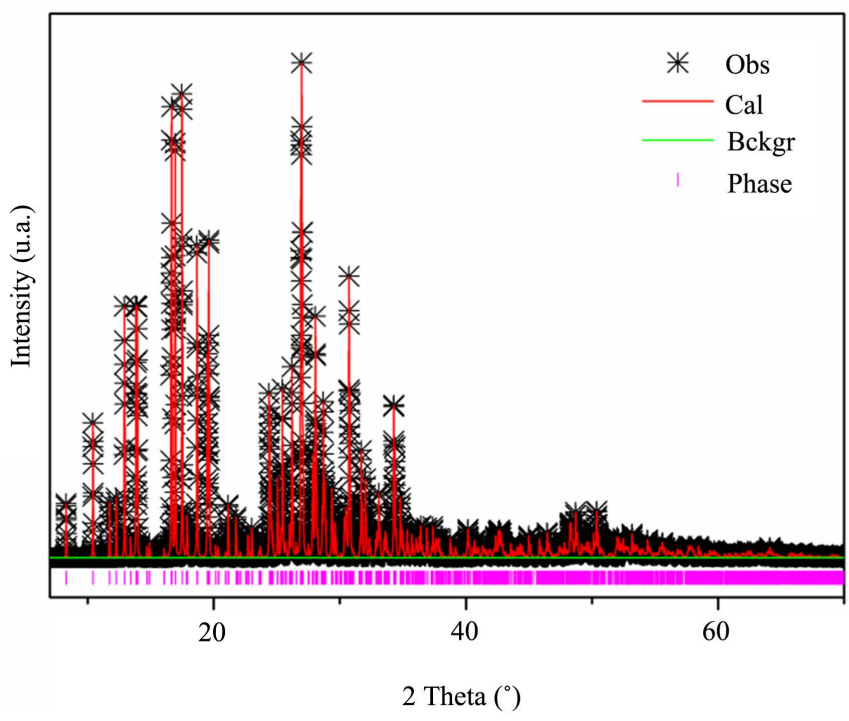

Figure 6. Experimental and calculated powder $\mathrm{X}$-ray diffraction patterns of $\mathrm{FeCl}_{4}\left(\mathrm{C}_{5} \mathrm{~N}_{2} \mathrm{H}_{6}\right)\left(\mathrm{C}_{5} \mathrm{~N}_{2} \mathrm{H}_{5}\right)$.

\subsection{IR Spectrum}

To gain more information on the functional groups present in the complex, we have used the infrared spectroscopy technique. The IR spectrum of the compound $\mathrm{FeCl}_{4}\left(\mathrm{C}_{5} \mathrm{~N}_{2} \mathrm{H}_{6}\right)\left(\mathrm{C}_{5} \mathrm{~N}_{2} \mathrm{H}_{5}\right)$ recorded at room temperature in the region 400 $4000 \mathrm{~cm}^{-1}$ is depicted in Figure 7.

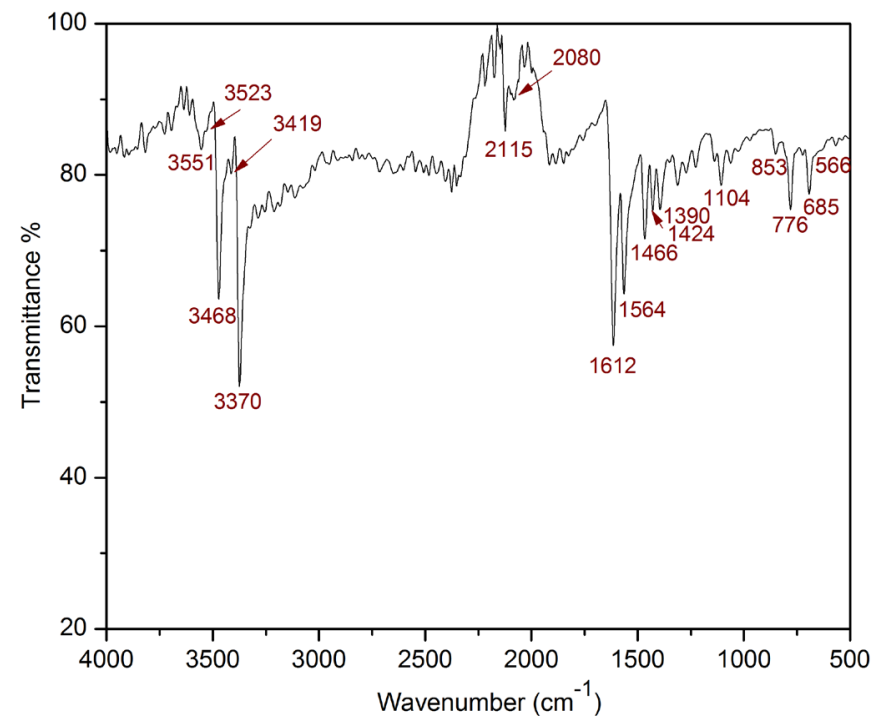

Figure 7. IR spectrum of the compound $\mathrm{FeCl}_{4}\left(\mathrm{C}_{5} \mathrm{~N}_{2} \mathrm{H}_{6}\right)\left(\mathrm{C}_{5} \mathrm{~N}_{2} \mathrm{H}_{5}\right)$. 
In the region $3700-2700 \mathrm{~cm}^{-1}$ the broad and strong bands are indicative of intermolecular hydrogen bonding interactions [22]. The bond at 3551 and 3523 $\mathrm{cm}^{-1}$ are due to the N-H asymmetric stretching and symmetric stretching vibrations respectively [23]. The bonds at $3468,3419 \mathrm{~cm}^{-1}$ were assigned to the asymmetric and symmetric $\mathrm{NH}_{2}$ stretching vibrations of the amine group respectively [24].

The aromatic C-H stretching vibration appears at $3370 \mathrm{~cm}^{-1}$ [25].

The peaks around 1612,1564 and $1466 \mathrm{~cm}^{-1}$ are due to the $\mathrm{C}=\mathrm{C}, \mathrm{C}=\mathrm{N}$ and $\mathrm{C}-\mathrm{C}$ stretching modes of the aromatic rings [24] [25] [26].

The bonds at 1424 and $1390 \mathrm{~cm}^{-1}$ are consistent with asymmetric and symmetric C-N stretching vibrations respectively [24].

The weak bands are located at 1104 and $853 \mathrm{~cm}^{-1}$ are due to the $v\left(\mathrm{C}-\mathrm{N}_{\text {aromatic }}\right)$ and $v(\mathrm{C}-\mathrm{H})$ modes [27].

A weak band that appears at $685 \mathrm{~cm}^{-1}$ is attributed to the $\mathrm{C}-\mathrm{Cl}$ bending vibration [24].

The peak above $350 \mathrm{~cm}^{-1}$ is assigned to $v(\mathrm{Fe}-\mathrm{Cl})$ [28] [29].

\subsection{UV-Vis Spectrum}

The obtained UV-Vis Spectrum for the compound $\mathrm{FeCl}_{4}\left(\mathrm{C}_{5} \mathrm{~N}_{2} \mathrm{H}_{6}\right)\left(\mathrm{C}_{5} \mathrm{~N}_{2} \mathrm{H}_{5}\right)$ hydrate in methanol was recorded at diluted concentration $\left(5 \times 10^{-4}\right)$. The UV-Vis Spectrum reveals an absorption band at $358 \mathrm{~nm}(<400 \mathrm{~nm})$ (Figure 8), indicates the $\pi-\pi$ transitions into the ligands. Thus, the value of the experimental band-gap energy $\left(\mathrm{E}_{\mathrm{g}}\right)$ estimated from the absorption edge wavelength is about $2.9 \mathrm{eV}$. This band-gap value confirms that the crystal exhibits semiconductor behaviour [30].

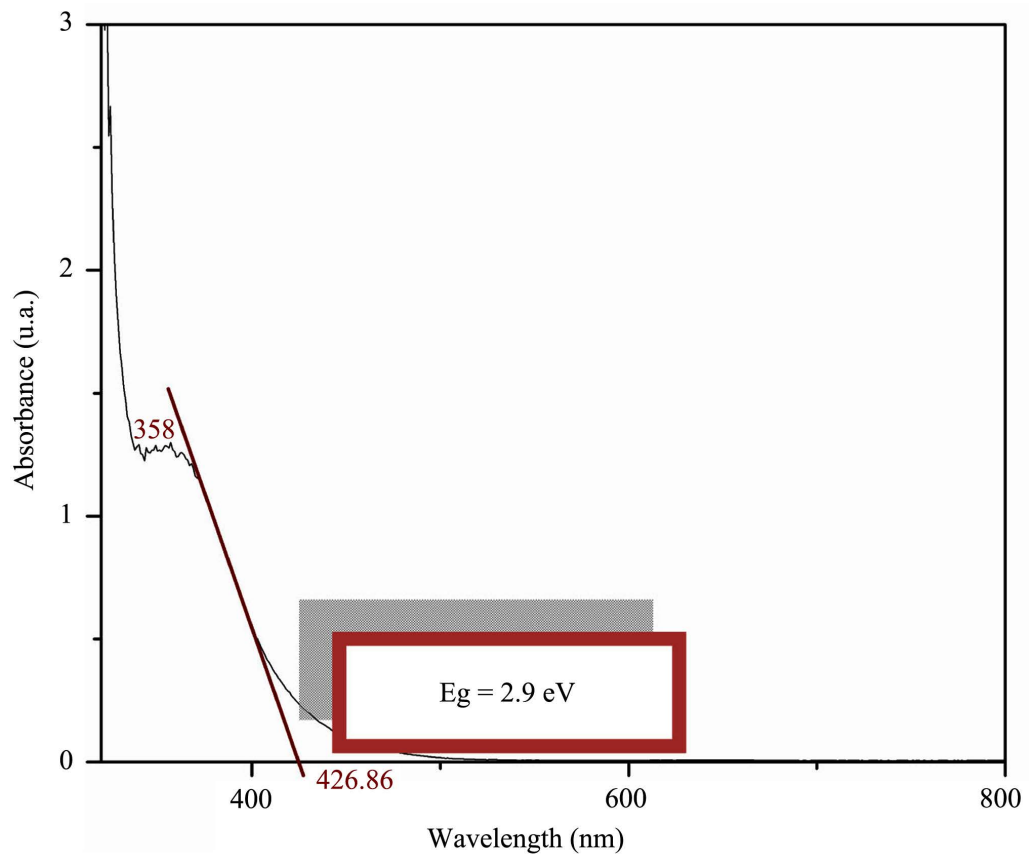

Figure 8. UV-Vis spectrum of the compound $\mathrm{FeCl}_{4}\left(\mathrm{C}_{5} \mathrm{~N}_{2} \mathrm{H}_{6}\right)\left(\mathrm{C}_{5} \mathrm{~N}_{2} \mathrm{H}_{5}\right)$. 


\subsection{Thermal Analysis of $\mathrm{FeCl}_{4}\left(\mathrm{C}_{5} \mathrm{~N}_{2} \mathrm{H}_{6}\right)\left(\mathrm{C}_{5} \mathrm{~N}_{2} \mathrm{H}_{5}\right)$}

The TGA-DTA of $\mathrm{FeCl}_{4}\left(\mathrm{C}_{5} \mathrm{~N}_{2} \mathrm{H}_{6}\right)\left(\mathrm{C}_{5} \mathrm{~N}_{2} \mathrm{H}_{5}\right)$ were performed on 10.9 mg under argon atmosphere, in the temperature range of $25^{\circ} \mathrm{C}-470^{\circ} \mathrm{C}$, at a heating rate of $10^{\circ} \mathrm{C} \cdot \mathrm{min}^{-1}$ (Figure 9). The thermogram analysis for this compound shows that it degraded in three steps. First step represented that the percentage of the experimental mass loss is in the order of $1.329 \%$ (calculated $0.44 \%$ ), in the temperature ranging from $80^{\circ} \mathrm{C}-140^{\circ} \mathrm{C}$, which the departure of $\mathrm{H}_{2}$. This step is characterized by two endothermic peaks in a temperature range of $53^{\circ} \mathrm{C}-100^{\circ} \mathrm{C}$.

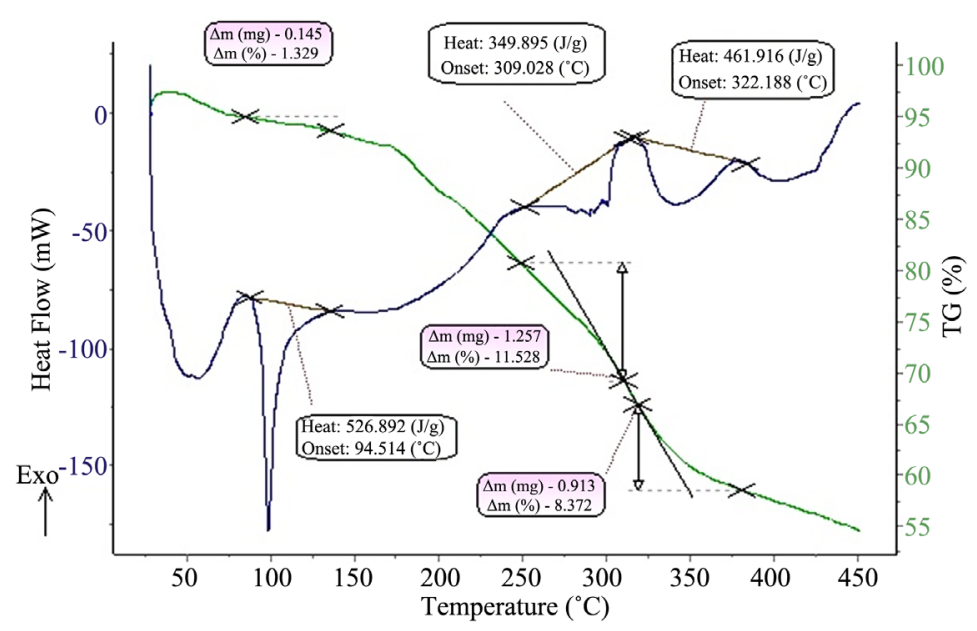

Figure 9. Thermal analysis of the title compound $\mathrm{FeCl}_{4}\left(\mathrm{C}_{5} \mathrm{~N}_{2} \mathrm{H}_{6}\right)\left(\mathrm{C}_{5} \mathrm{~N}_{2} \mathrm{H}_{5}\right)$.

The second step involved a second loss mass corresponding to the decomposition of part of the organic base $(\mathrm{NH}$ and $\mathrm{HCl})$ in the temperature ranging from $250^{\circ} \mathrm{C}-325^{\circ} \mathrm{C}$ (experimental $11.528 \%$, calculated $11.30 \%$ ) [31] [32]. This stage is characterized by an endothermic peak at $298^{\circ} \mathrm{C}$. In the final step, the TG trace shows an $8.372 \%$ loss in weight, which is calculated in the order of $10.02 \%$ in the range $330^{\circ} \mathrm{C}-378^{\circ} \mathrm{C}$, indicating the conversion to $1 / 2 \mathrm{FeCl}$ [33]. This step is corresponded to an endothermic peak at $348^{\circ} \mathrm{C}$.

\section{Hirshfeld Surface Analysis}

A Hirshfeld surface analysis and the associated 2D-fingerprint plots are the convenient way to investigate different types of intermolecular interactions and to dissect crystal structures into non-covalent contacts [34] [35] by the aid of Crystal Explorer program [36]. Figure 10(a) illustrates the Hirshfeld surface mapped over $\mathrm{d}_{\text {norm }}$ using different colours. Red areas highlight the closer contacts including the $\mathrm{N}-\mathrm{H} \cdots \mathrm{Cl}$ hydrogen bonds. Blue areas represent longer contacts (no interactions) [26]-[37]. In the shape-index map (Figure 10(b)), the adjacent red and blue triangle show concave regions that confirm the presence of the $\pi-\pi$ interaction.

The 2D fingerprint plot shows the different types of interaction that assure the structure cohesion (Figure 11). The $\mathrm{Cl} \cdots \mathrm{H} / \mathrm{H} \cdots \mathrm{Cl}$ play a dominant role with a significant contribution of $68.4 \%$ and the $\mathrm{Cl} \cdots \mathrm{Cl}$ contacts contributed with an 


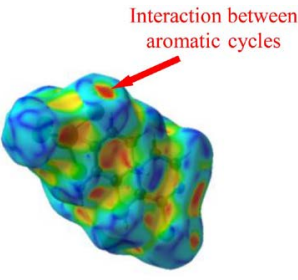

(a)

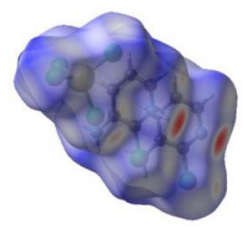

(b)

Figure 10. View of the Hirshfeld surfaces for $\mathrm{FeCl}_{4}\left(\mathrm{C}_{5} \mathrm{~N}_{2} \mathrm{H}_{6}\right)\left(\mathrm{C}_{5} \mathrm{~N}_{2} \mathrm{H}_{5}\right)$ mapped over (a) $\mathrm{d}_{\text {norm }}$ and (b) shape-index, displaying the intermolecular interactions.

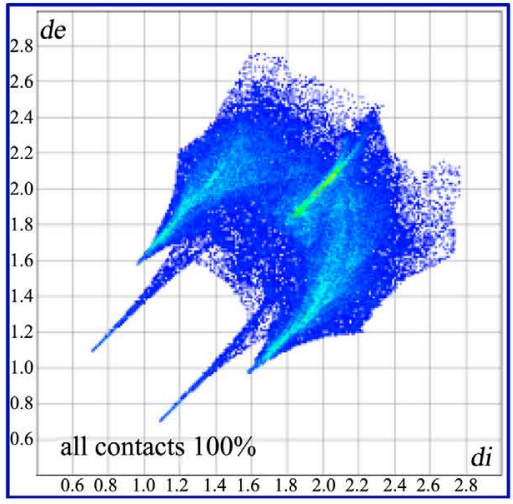

(a)

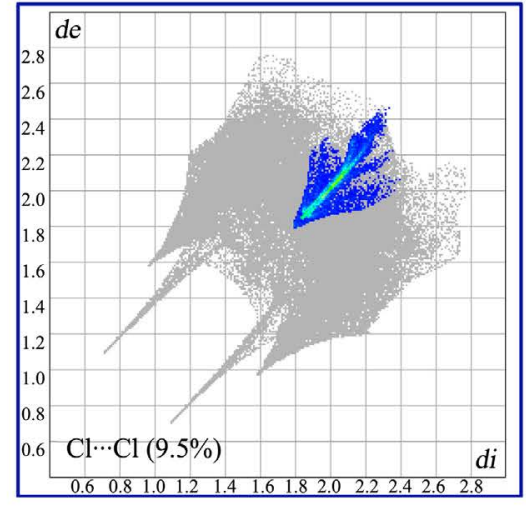

(c)

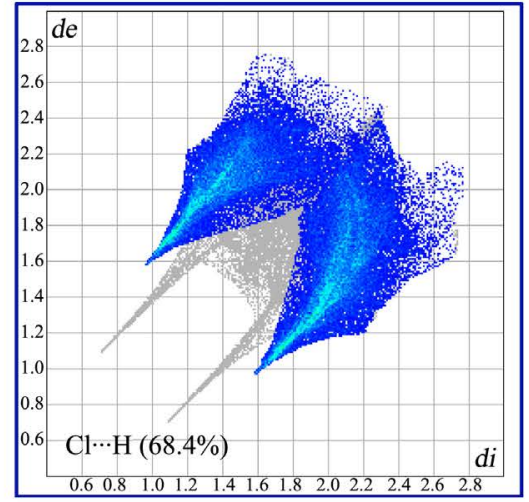

(b)

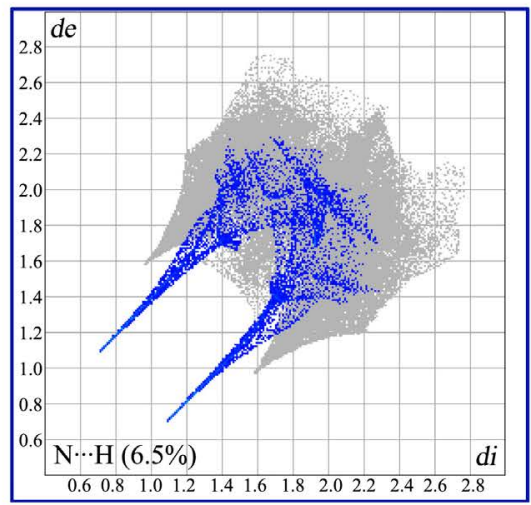

(d)

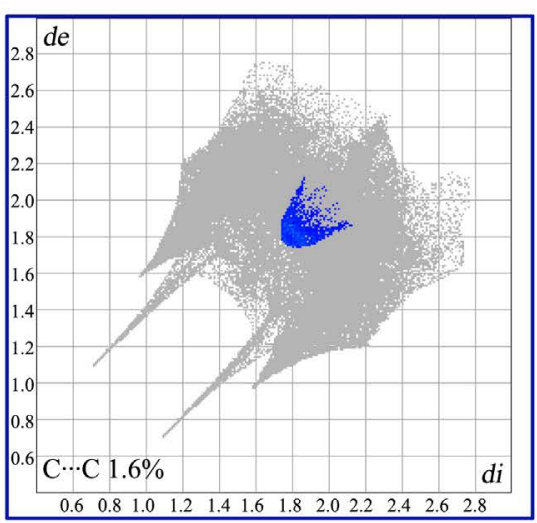

(e)

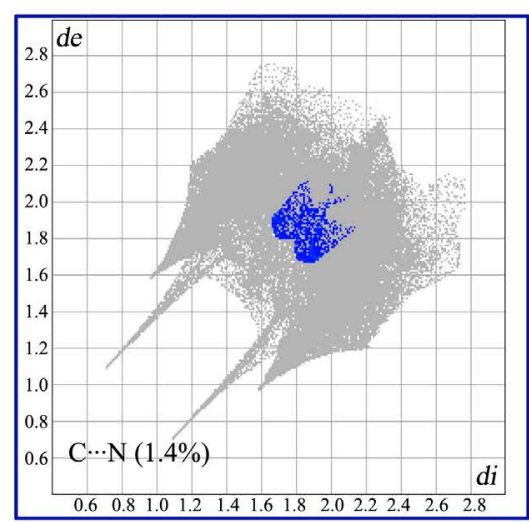

(f)

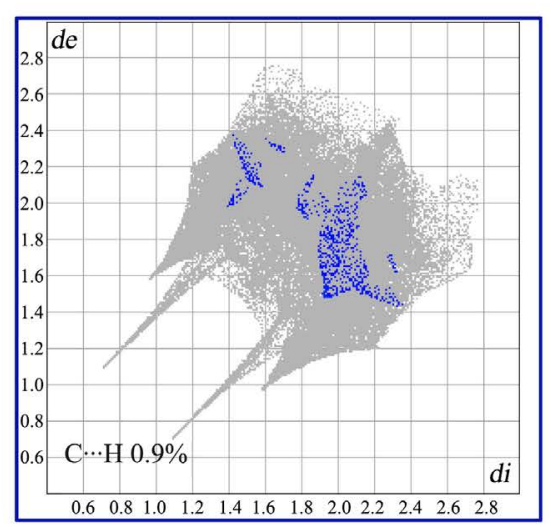

(g)

Figure 11. Full two-dimensional fingerprint plots showing all interactions, $\mathrm{Cl} \cdots \mathrm{H}(68.4 \%), \mathrm{Cl} \cdots \mathrm{Cl}(9.5 \%), \mathrm{N} \cdots \mathrm{H}(6.5 \%), \mathrm{C} \cdots \mathrm{C}$ $(1.6 \%), \mathrm{C} \cdots \mathrm{N}(1.4 \%)$ and $\mathrm{C} \cdots \mathrm{H}(0.9 \%)$. 
equal minor percentage at $9.5 \%$. The contact $\mathrm{N} . . . \mathrm{H} / \mathrm{H}$...N appears as a symmetrical tip shape with $6.5 \%$ of the total surface Hirshfeld area. Furthermore, the C...C contact contributed to the $2 \mathrm{D}$ fingerprint with an equal minor percentage at $1.6 \%$ confirms the presence of $\pi-\pi$ interactions between the rings of 3-amino-2-chloropyridinium cations.

\section{Conclusion}

Red crystals of the new iron complex $\mathrm{FeCl}_{4}\left(\mathrm{C}_{5} \mathrm{~N}_{2} \mathrm{H}_{6}\right)\left(\mathrm{C}_{5} \mathrm{~N}_{2} \mathrm{H}_{5}\right)$ were successfully synthesized by slow evaporation at room temperature. This compound crystallizes in the monoclinic system with the $\mathrm{P}_{1} / \mathrm{c}$ space group and is solved through single crystal X-ray diffraction. The PXRD confirms a high purity of the synthesized sample. The IR Spectroscopy technique was used to identify the vibrational absorption bonds of the crystal structure. Thus, the optical properties were performed by measuring the diffuse reflectance and the band-gap energy $\left(\mathrm{E}_{\mathrm{g}}\right)$ of this compound was found to be at $2.9 \mathrm{eV}$. The results of thermal analysis TGA-DTA were obtained to prove the thermal stability of the complex. The cohesion and the stability result from the establishment of hydrogen-bonding network consisting of $\mathrm{N}-\mathrm{H} \cdot \cdots \mathrm{Cl}$ and $\pi-\pi$ interactions between rings. Moreover, The Hirshfeld surface and fingerprints plots analysis showed the existence of intermolecular interactions in which $\mathrm{N}-\mathrm{H} \cdots \mathrm{Cl}$ is the most abundant in this crystal structure.

\section{Acknowledgements}

Financial support from the Ministry of Higher Education and Scientific Research of Tunisia is gratefully acknowledged.

\section{Conflicts of Interest}

The authors declare no conflicts of interest regarding the publication of this paper.

\section{References}

[1] Dong, Q., Wang, H., Liu, Q., Ji, S., Zhang, Y., Tang, C., Wang, X. and Wang, R. (2020) Simplifying the Creation of Iron Compound Inserted, Nitrogen-Doped Carbon Nanotubes and Its Catalytic Application. Journal of Alloys and Compounds, 857, Article ID: 157543. https://doi.org/10.1016/j.jallcom.2020.157543

[2] Tavallali, V., Rowshan, V., Gholami, H. and Hojat, S. (2020) Iron-Urea Nano-Complex Improves Bioactive Compounds in Essential Oils of Ocimum basilicum L. Scientia Horticulturae, 265, Article ID: 109222.

https://doi.org/10.1016/j.scienta.2020.109222

[3] Caetano-Silva, M.E., Alves, R.C., Lucena, G.N., Galvão Frem, R.C., Bertoldo-Pacheco, M.T., Azevedo Lima-Pallone, J. and Netto, F.M. (2017) Synthesis of Whey Peptide-Iron Complexes: Influence of Using Different Iron Precursor Compounds. Food Research International, 101, 73-81. https://doi.org/10.1016/j.foodres.2017.08.056

[4] Fadeeva, I.V., Trofimchuk, E.S., Dedushenko, S.K., Fomina, A.S., Davydova, G.A., Selezneva, I.I., Perfiliev, Y.D. and Barinov, S.M. (2019) Methylcellulose Films Par- 
tially Crosslinked by Iron Compounds for Medical Applications. Materials Today Communications, 18, 54-59. https://doi.org/10.1016/j.mtcomm.2018.10.008

[5] Benamrane, A., Herry, B., Vieru, V., Chakraborty, S., Biswas, S., Prince, S., Marschner, C. and Blom, B. (2020) Ionic Ruthenium and Iron Based Complexes Bearing Silver Containing Anions as a Potent New Class of Anticancer Agents. Journal of Organometallic Chemistry, 934, Article ID: 121659.

https://doi.org/10.1016/j.jorganchem.2020.121659

[6] Rebellato, A.P., Klein, B., Wagner, R. and Azevedo Lima Pallone, J. (2018) Fortification Effects of Different Iron Compounds on Refined Wheat Flour Stability. Journal of Cereal Science, 82, 1-7. https://doi.org/10.1016/j.jcs.2018.05.006

[7] Hanket, T., Brunne, R.M., Müller, H. and Reichel, F. (1999) Statistical Investigation into the Structural Complementarity of Natural Products and Synthetic Compounds. Angewandte Chemie International Edition, 38, 643-647.

https://doi.org/10.1002/(SICI)1521-3773(19990301)38:5<643::AID-ANIE643>3.0.C $\underline{\mathrm{O} ; 2-\mathrm{G}}$

[8] Henry, G.D. (2004) De Novo Synthesis of Substituted Pyridines. Tetrahedron, 60, 6043-6061. https://doi.org/10.1016/j.tet.2004.04.043

[9] Janiak, C. (2000) A Critical Account on Pep Stacking in Metal Complexes with Aromatic Nitrogen-Containing Ligands. Journal of the Chemical Society, 21, 3885-3896. https://doi.org/10.1039/b003010o

[10] Desiraju, G.R. (2005) C-H/...O and Other Weak Hydrogen Bonds. From Crystal Engineering to Virtual Screening. Chemical Communications, 24, 2995-3001. https://doi.org/10.1039/b504372g

[11] Sun, H.S., Xu, Y.M., He, W., Tang, S.G. and Guo, C. (1989) (Z)-5-(4-Fluoro benzyl idene)-1,3-thia Zolidine-2,4-dione, Enraf Nonius, CAD4, Solfware, Version 5.0.

[12] Burla, M.C., Caliandro, R., Carrozzini, B., Cascarano, G.L., Cuocci, C., Giacovazzo, C., Mallamo, M., Mazzone, A. and Polidori, G. (2014) Crystal Structure Determination and Refinement via SIR 2014. Journal of Applied Crystallography, 48, 306-309. https://doi.org/10.1107/S1600576715001132

[13] Sheldrick, G.M. (2015) Crystal Structure Refinement with SHELXL. Acta Crystallographica C, 71, 3-8. https://doi.org/10.1107/S2053229614024218

[14] North, A.C.T., Phillips, D.C. and Mathews, F.S. (1968) A Semi-Empirical Method of Absorption Correction. Acta Crystallographica Section A, 24, 351-359. https://doi.org/10.1107/S0567739468000707

[15] Brandenburg, K. (1998) Diamond, Version 3.2. Crystal Impact GbR, Bonn.

[16] Jellali, A., Hamdi, B., Samet, A. and Zouari, R. (2018) Experimental, Theoretical, Characterization and Optical Investigation of a New Hybrid Material (8-HQ)2[FeCl4]Cl. Journal of Molecular Structure, 1171, 305-314.

https://doi.org/10.1016/j.molstruc.2018.05.114

[17] Hammami, I., Dhifallah, F., Ouari, K., Belkhiria, M.S. and Nasri, H. (2018) A New Assembly of a Wells-Dawson Polyoxometalate-Based Iron(III) Coordination Complex Hybrid: Synthesis, Crystal Structure, Thermal and Electrochemical Properties. Polyhedron, 160, 63-67. https://doi.org/10.1016/j.poly.2018.12.034

[18] Baur, W.H. (1974) The Geometry of Polyhedral Distortions. Predictive Relationships for the Phosphate Group. Acta Crystallographica Section B Structural Crystallography and Crystal Chemistry, 30, 1195-1215.

https://doi.org/10.1107/S0567740874004560

[19] Chérif, I., Abdelhak, J., Zid, M.F. and Driss, A. (2012) 2-Amino-5-chloropyridinium Cis-diaquadioxalatochromate(III) Sesquihydrate. Acta Crystallographica Section E 
Structure Reports Online, 68, m824-m825.

https://doi.org/10.1107/S1600536812023392

[20] Larson, A.C. and Von Dreele, R.B. (2000) General Structure Analysis System (GSAS) Report LAUR 86-748. Los Alamos National Laboratory, Los Alamos.

[21] Toby, B.H. (2001) EXPGUI, Graphical User Interfaces for GSAS. Journal of Applied Crystallography, 34, 210-213. https://doi.org/10.1107/S0021889801002242

[22] Kvick, A., Thomas, R. and Koetzle, T.F. (1976) Hydrogen Bond Studies. CI. A Neutron Diffraction Study of 2-Amino-5-chloropyridine. Acta Crystallographica Section B Structural Crystallography and Crystal Chemistry, 32, 224-231. https://doi.org/10.1107/S0567740876002641

[23] Muthu, S. and Renuga, S. (2014) Vibrational Spectra and Normal Coordinate Analysis of 2-Hydroxy-3-(2-methoxyphenoxy) Propyl Carbamate. Spectrochimica Acta Part A, 132, 313-325. https://doi.org/10.1016/j.saa.2014.05.009

[24] Madhankumar, S., Muthuraja, P. and Dhandapanin, M. (2019) Physico-Chemical Characterization and Computational Studies of a New Organic Adduct 3-Amino2-chloropyridine: Benzilic Acid, Crystal for Third Order Harmonic Generation. Journal of Molecular Structure, 1203, Article ID: 127415. https://doi.org/10.1016/j.molstruc.2019.127415

[25] Suthan, T., Rajesha, N.P., Mahadevan, C.K. and Bhagavannarayana, G. (2011) Studies on Crystal Growth and Physical Properties of 2-Amino-5-chloropyridine Single Crystal. Materials Chemistry and Physics, 129, 433-438.

https://doi.org/10.1016/j.matchemphys.2011.04.038

[26] Garci, F., Ferjani, H., Chebbi, H., Ben Jomaa, M. and Zid, M.F. (2019) Crystal Structure, Hirshfeld Surface Analysis and Physicochemical Characterization of Bis[4-(dimethylamino)pyridinium]di- $\mu$-chlorido-bis[dichloridomercurate(II)]. Acta Crystallographica Section E, 75, 1600-1606. https://doi.org/10.1107/S2056989019013124

[27] Dobrzynska, D., Jerzykiewicz, L.B., Duczmal, M. and Wojciechowska, A. (2011) Synthesis, Structure, Magnetic and Spectroscopic Properties of Chromium(III) Complex with Quinoline-2-Carboxylate Ion. Polyhedron, 30, 2684-2689.

https://doi.org/10.1016/j.poly.2011.07.018

[28] Sreekanth, A., Fun, H.K. and Prathapachandra Kurup, M.R. (2005) Structural and Spectral Studies of an Iron(III) Complex [Fe(Pranthas)2] $\left[\mathrm{FeCl}_{4}\right]$ Derived from 2-Acetylpyridine- $\mathrm{N}(4) \mathrm{N}(4)$-(butane-1,4-diyl)thiosemicarbazone (HPranthas). Journal of Molecular Structure, 737, 61-67. https://sci-hub.st/10.1016/j.molstruc.2004.10.036 https://doi.org/10.1016/j.molstruc.2004.10.036

[29] Selmi, W., Abdelhak, J., Arfaoui, A., Amri, H., Boujlel, K., Zid, M.F. and Driss, A. (2014) Oxalate-Bridged Binuclear Iron(III) Complexes of 3,5-Dimethylpyrazole Ligands: Synthesis, Structure, Spectral and Electrochemical Properties. International Journal of Chemical Engineering, 31, 2051-6051.

[30] Rosencher, E. and Vinter, B. (2002) Optoelectronics. Cambridge University Press, Cambridge. https://doi.org/10.1017/CBO9780511754647

[31] Dgachi, S., Turnbull, M.M., Mezzadri, F., Norquist, A.J., Soran A., Boonmak, J., Nemes, G. and Naïli, H. (2020) Polymorphism in the Metal-Organic Hybrid $\left(\mathrm{PhCH}_{2} \mathrm{NEt}_{3}\right)_{2}\left[\mathrm{CoBr}_{4}\right]$ : Synthesis, Crystal Structures and Physico-Chemical Characterizations. Inorganica Chimica Acta, 514, Article ID: 119997.

https://sci-hub.st/10.1016/j.ica.2020.119997 https://doi.org/10.1016/j.ica.2020.119997

[32] Hfdhi, N., Krayem, N., Erwann, J., Bataille, T. and Naili, H. (2020) Lamellar and Supramolecular Feature of New Tutton's Salts Incorporating 2-Amino-4-Methylpyrimidine: 
Thermal Stability, Optic Study, Antioxidant and Antimicrobial Activities. Journal of Inorganic and Organometallic Polymers and Materials.

https://sci-hub.st/10.1007/s10904-020-01817-x https://doi.org/10.1007/s10904-020-01817-x

[33] Maatar Ben Salah, A., Herrera, R.P. and Naili, H. (2018) Hydrothermal Synthesis of Chiral Inorganic-Organic Co II Complex: Structural, Thermal and Catalytic Evaluation. Journal of Molecular Structure, 1165, 356-362.

https://sci-hub.st/10.1016/j.molstruc.2018.04.002 https://doi.org/10.1016/j.molstruc.2018.04.002

[34] Spackman, M.A. and McKinnon, J.J. (2002) Fingerprinting Intermolecular Interactions in Molecular Crystals. CrystEngComm, 4, 378-392. https://doi.org/10.1039/B203191B

[35] McKinnon, J.J., Spackman, M.A. and Mitchell, A.S. (2004) Novel Tools for Visualizing and Exploring Intermolecular Interactions in Molecular Crystals. Acta Crystallographica, 60, 627-668. https://doi.org/10.1107/S0108768104020300

[36] Rohl, A.L., Moret, M., Kaminsky Clabron, W.K., Mckinnon, J.J. and Kahr, B. (2008) Hirshfeld Surfaces Identify Inadequacies in Computations of Intermolecular Interactions in Crystals: Pentamorphic 1,8-Dihydroxyanthraquinone. Crystal Growth \& Design, 12, 4517-4525. https://doi.org/10.1021/cg8005212

[37] Ben Moussa, O., Chebbi, H. and Zid, M.F. (2019) Synthesis, Crystal Structure, Vibrational Study, Optical Properties and Hirshfeld Surface Analysis of Bis(2,6diaminopyridinium) Tetrachloridocobaltate(II) Monohydrate. Journal of Molecular Structure, 1180, 72-80. https://doi.org/10.1016/j.molstruc.2018.11.077 